\title{
Revestir el poder en tiempos de cambio: el uso de la toga entre las elites ibéricas (ss. II-I a. C.)*
}

\section{Vest power in times of change: the wearing of the toga among Iberian elites ( $\mathrm{II}^{\mathrm{nd}}-\mathrm{I}^{\text {st }}$ centuries BC)}

\author{
Jorge García Cardiel ${ }^{1}$ \\ Universidad Autónoma de Madrid - Grupo Occidens
}

\begin{abstract}
RESUMEN
En el presente artículo se estudian conjuntamente las representaciones de togados halladas entre los exvotos antropomorfos de varios santuarios ibéricos y las menciones que Estrabón desgrana sobre los “togados/estolados” hispanos. Frente a la interpretación tradicional de unos y otras como indicios del grado de aculturación y el estatuto jurídico alcanzados por sus portadores, argumentamos que la toga sería empleada por determinados iberos como materialización visible de su condición de amici populi romani, formando parte por tanto de una estrategia ideológica en el marco de la competición por el poder en sus respectivas comunidades.
\end{abstract}

\section{SUMMARY}

This paper studies both the representations of togati found among the anthropomorphic votive figures of several Iberian sanctuaries, and Strabo's remarks about Hispanic "togati/ stolati". Typically, scholars take both of them as indicators of the acculturation degree or the juridical status achieved by their users. However, we argue that some Iberians dressed the toga as a conspicuous materialization of their condition as amici populi romani. Its use would be part of an ideological strategy in the context of power struggles within their communities.

PALABRAS CLAVE: romanización; santuarios; mímesis; identidad; amicitia.

KEY WORDS: Romanization; sanctuaries; mimesis; identity; amicitia.

COMO CITAR ESTE ARTÍCULO / CITATION: García Cardiel, J. 2019: "Revestir el poder en tiempos de cambio: el uso de la toga entre las elites ibéricas (ss. II-I a. C.)", Archivo

\footnotetext{
* Este trabajo se enmarca en el proyecto de investigación PGC2018-096415-B-C21, financiado por el Ministerio de Ciencia, Innovación y Universidades.

1 jorge.garciac@uam.es / ORCID iD: https://orcid.org/00000002-1093-8129
}

Español de Arqueología 92, 155-171. https://doi.org/10.3989/ aespa.092.019.008

\section{INTRODUCCIÓN}

A modo de corolario de su descripción de la Turdetania $^{2}$, Estrabón sistematiza sucintamente el proceso que, a su modo de ver, había llevado a algunos turdetanos (y, junto con ellos, a otros pueblos hispanos) a alcanzar las más altas cotas de civilización. La abundancia de recursos naturales y la convivencia cotidiana con los colonos romanos habían motivado, según él, que algunas de estas gentes se hubieran pacificado, hubieran olvidado sus costumbres ancestrales ( $i$ h hasta su propia lengua!) y hubieran adoptado el modo de vida civilizado, esto es, el romano. Muchos de ellos gozaban ya del estatuto jurídico latino, y poco les faltaba para convertirse en romanos propiamente dichos. Tan es así, que habían adoptado la toga por vestuario: es por eso que se les llamaba "togados".

\footnotetext{
${ }^{2}$ Vaya por delante mi agradecimiento a E. Sánchez Moreno, T. Chapa y S. Montero por la enriquecedora discusión de algunas de las ideas argumentadas en este trabajo. Quisiera agradecer también a T. Chapa y A. Rodero su amabilidad al permitirme hacer uso de las fotografías del Cerro de los Santos tomadas durante un estudio conjunto. Agradezco asimismo a P. Cabrera y al Museo Arqueológico Nacional su ayuda al facilitarme el estudio de las terracotas de los Altos del Sotillo conservadas en la mencionada institución.

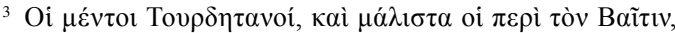

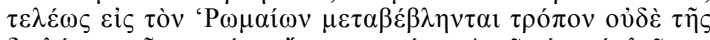

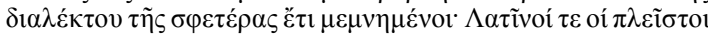

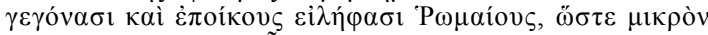

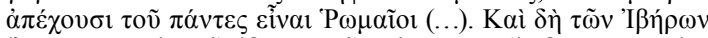

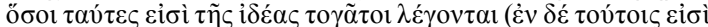

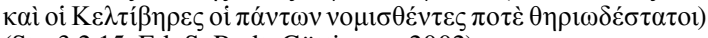
(Str. 3.2.15. Ed. S. Radt. Göttingen, 2002).
} 
Más allá de los diversos problemas interpretativos de los que adolece esta reflexión, y que trataré por lo menudo más adelante, por el momento advirtamos simplemente los dos pilares conceptuales sobre los que Estrabón elabora su discurso, y sobre los que pivotará el presente trabajo: la integración de las comunidades locales hispanas en las estructuras culturales romanas y el papel que la vestimenta desempeñó en dicho proceso.

La primera de estas nociones se inscribe en el núcleo del famoso paradigma moderno de la romanización, clave en la interpretación académica de la expansión romana por el Mediterráneo durante el último siglo. Las diversas comunidades locales que entraban en contacto con Roma pronto reconocían la superioridad de las estructuras culturales imperiales, por lo que paulatinamente, y si las condiciones físicas de su territorio lo permitían, tendían a imitar dichas estructuras hasta lograr una asimilación completa. Este paradigma, no obstante, ha venido siendo objeto de diversas y duras críticas en las últimas décadas, focalizadas en su génesis imperialista (no en vano esta línea interpretativa se gestó durante la etapa de auge de los imperialismos modernos, como epifenómeno legitimatorio de estos), en su carácter unidireccional y teleológico, y en la concepción esencialista de cultura sobre la que se asienta. La perspectiva tradicional de la romanización tiende a presentar un panorama demasiado homogéneo y unilineal, que obvia como "rémora" cualquier realidad cultural diferente del modelo definido como romano, asume la existencia de culturas independientes, estancas y homogéneas, niega la agencia de las comunidades locales y centra sus esfuerzos en ponderar el grado de asimilación al modelo romano en vez de estudiar la naturaleza y mecanismos del encuentro colonial (Barret 1997; Woolf 1998; Millett 2010; Mattingly 2011). Todo lo cual no obsta, sin embargo, para que diversos especialistas todavía hoy continúen abogando por la utilidad de esta línea argumentativa, bien que matizada, señalando a su vez que los críticos con el concepto de "romanización" tienden a presentar imágenes irénicas del contacto cultural, minimizando los desequilibrios de fuerzas entre los agentes implicados y el éxito globalizador, a la postre, de las estructuras imperiales romanas (Hanson 1997; Alföldy 2005; Whittaker 2009; Dmitriev 2009; Bardet 2010; Van Oyen 2015; Beltrán 2017).

El párrafo que nos ocupa, de hecho, ha sido esgrimido como argumento en esta polémica desde posicionamientos muy diferentes. Una lectura positivista de Estrabón lleva a considerar que parte de los turdetanos y celtíberos habían alcanzado ya elevadas cotas de romanización gracias a la convivencia con los colonos romanos y a la feracidad del territorio hispano, prueba de lo cual era su olvido de sus antiguas costumbres y el empleo de la toga ( $c f$., por ejemplo, Baena 1993: 170-171; Blázquez 2006: 245). Otros autores, en cambio, optan por matizar el razonamiento de Estrabón, enfatizando la agencia de las poblaciones hispanas: más allá de que la prosperidad ambiental y el contacto cotidiano con los colonos romanos posibilitaran el proceso, fueron los actores locales quienes voluntariamente protagonizaron un acercamiento a los modos de vida romanos (Le Roux 1995: 11-16; Woolf 1998: 65-68). Ahora bien, merece la pena rescatar aquí las recientes reflexiones de Hæussler acerca de este tipo de lecturas. Según el historiador alemán, al tratar estos procesos debemos prestar atención preferente a la diversidad de agendas y motivaciones, incluso en aquellos casos en los que nos encontremos con una aparente confluencia de comportamientos (Hæussler 2013: 25-26). Y debemos reparar en la problemática de aceptar la existencia empírica de una Romanitas uniforme y preexistente a la que los agentes locales pudieran acercarse (Hæussler 2013: 51-59).

La segunda de las ideas clave del pasaje estraboniano es la de que el proceso de romanización llevó a la asunción de la toga por parte de las sociedades más civilizadas, "casi romanas". Es esta una de esas relaciones causales que se suelen dar por sentadas, pero sobre las que merece la pena reflexionar: ¿por qué asumimos el uso de la toga como culminación lógica del proceso civilizatorio hispano? ¿Acaso todos los ciudadanos romanos de todas las provincias la portaban a finales de la República? ¿La portaban, siquiera, los hispanos? ¿Tendrían derecho a portarla quienes, como reconoce el propio Estrabón, no eran todavía del todo romanos?

Con esta cuestión, nos adentramos en un campo de las ciencias humanas que comienza a desarrollarse en las últimas décadas: la "corporalidad" (embodiment) de la cultura y su relación con los discursos identitarios. Partiendo de los postulados de grandes teóricos de la sociología como Foucault, Bourdieu o Douglas, los últimos estudios tienden a contemplar el cuerpo humano (y, por extensión, su exposición/ocultación a través del atuendo) como un constructo en constante transformación, con fronteras flexibles y fluidas, a través del que se crea y negocia la identidad y la cosmogonía del individuo. Las experiencias y sensaciones, pero también los movimientos (voluntarios o no, cotidianos o rituales) y la propia construcción del cuerpo, son, por consiguiente, fenómenos culturalmente mediatizados, pero que al mismo tiempo modelan la cultura. Semejante aproximación epistemológica no ha tardado en aplicarse a la arqueología, con resultados ciertamente prometedores ( $c f$., por ejemplo, Hamilakis et alii 2002; Boric y Robb 2008; Bulger y Joyce 2012).

Por lo que a la vestimenta romana respecta, en los últimos años los estudios tradicionales, centrados en la 
identificación, funcionalidad y ordenación tipológica de las distintas prendas (vid., por ejemplo, Heuzey 1922: 227-279; Wilson 1924; Chapot 1937; Goethert 1939; Niemeyer 1968; Kleiner 1977; Goette 1990), se vienen complementando con nuevas aproximaciones interesadas en el papel del atuendo, y de la toga en particular, como signo transmisor y creador de significados culturales e identitarios, continuamente resemantizado según el contexto y la situación comunicativa concreta (Gregory 1994; Vout 1996; Cleland et alii 2005; Rothe 2009; Rothfus 2010; Larsson Lovén 2014).

Desde mi punto de vista, esta última perspectiva resulta sumamente fructífera para el análisis del pasaje estraboniano al que antes aludía y de ciertas representaciones iconográficas de togados que aparecen en los santuarios ibéricos de los siglos II y I a. C., de las que luego hablaré. El objetivo último de estas páginas, por consiguiente, será profundizar en los mecanismos de negociación e interacción política que operaron en la Hispania de los siglos II y I a. C., centrándonos para la ocasión en el estudio del uso de la toga entre los iberos. Para ello me alejaré de su interpretación tradicional como signo revelador de aculturación romanizadora, y la concebiré más bien como estrategia discursiva, implementada por determinados agentes en un contexto comunicativo multipolar, y con una intención que ha de ser convenientemente evaluada. Acaeciendo todo ello, por supuesto, en el marco de reajustes, coacciones, acuerdos y negociaciones desatados con la creación y consolidación de las estructuras provinciales romanas en la Hispania de los siglos II y I a. C.

\section{ESTRABÓN Y LOS ¿TOGATI? HISPANOS}

Regresemos al pasaje de Estrabón sobre los togados hispanos. Parece obvio que su estudio debe realizarse en paralelo a este otro pasaje de la Geografía, pues ambas referencias dialogan entre sí, ambas parecen adiciones conclusivas a sus respectivos capítulos, y ambas tienen en común ser las únicas ocasiones en las que el erudito de Amasia habla de "togados" en toda su colosal obra:

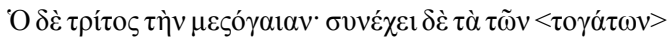

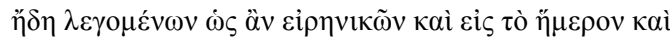

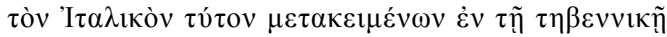

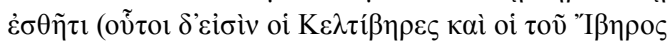

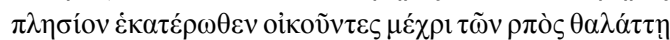
$\mu \varepsilon \rho \tilde{\omega} v)^{4}$.

${ }^{4}$ Str 3.4.20. Ed. S. Radt. Göttingen, 2002. "El tercero [legado] vigila las tierras del interior; se ocupa de los llamados ya togados, como si se les denominara 'pacíficos' y han cambiado
El análisis de las dos referencias, empero, debe partir de una incómoda constatación: en ninguno de los códices medievales que nos transmiten la Geogra-

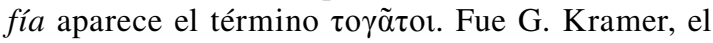
primer editor alemán de Estrabón, quien introdujo el vocablo en sustitución del adjetivo que incorporan los códices en el pasaje 3.2.15, $\sigma \tau \mathrm{\tau} \lambda \tilde{\alpha} \tau o$, considerando que subsanaba así un error de los copistas, pues, según él, la estola era para los romanos una prenda femenina, y además Dion Casio había hablado de una "Galia Togada" (y no "Estolada") en virtud precisamente de su alto grado de romanización ${ }^{5}$. Acto seguido, insertó

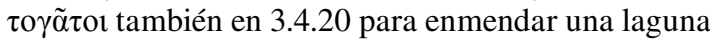
en los códices disponibles, empleando como argumentos la intertextualidad entre este parágrafo y el anterior y la yuxtaposición aquí con el adjetivo $\tau \eta \beta \varepsilon v \nu \imath \kappa \tilde{\eta}$, derivado según él del vocablo griego $\tau \eta ́ \beta \varepsilon v v \alpha$, "toga".

Ambas composturas han sido aceptadas por la mayoría de las ediciones posteriores de la Geografía (excepción hecha, por ejemplo, de F. Laserre 1966: 193, n. 9), y también, de forma más o menos crítica, por muchos de los estudios alusivos a ambos pasajes de Estrabón. En un sugerente artículo, sin embargo, A. M. Canto (2001) reexaminó la cuestión y propuso desechar estos aditamentos. Según la autora, es probable que el vocablo $\tau \eta \beta \varepsilon v v ı \kappa \tilde{~ q u e ~ f i g u r a ~ e n ~ 3.4 .20 ~ s e a ~ e n ~ r e a l i d a d ~}$ el resultado de una corrupción de la tradición manuscrita, pues esta es la única ocasión en la que aparece en la literatura griega antigua, y su supuesta deriva a partir del sustantivo $\tau \eta ́ \beta \varepsilon v v \alpha$ es ciertamente singular (Canto 2001: 458-461). Por otra parte, Canto demuestra que en las fuentes latinas más arcaicas la estola no era una prenda únicamente femenina, sino que se consideraba apta para ambos sexos o incluso preferentemente masculina, indistinguible de la toga hasta el punto de que, "entre la segunda mitad del siglo IV y el siglo II a. C., [toga y estola] eran la misma prenda" (Canto 2001: 463465). Privados de estos argumentos, y habida cuenta de la dificultad de comparar las provincias hispanas con la Galia Cisalpina en términos civilizatorios, concluye la autora, no puede defenderse la sustitución de $\sigma \tau 0 \lambda \tilde{\alpha} \tau o$ เ

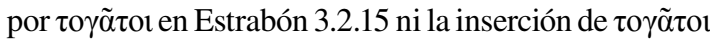
en 3.4.20. Los "togados" hispanos de los que hablaba el geógrafo de Amasia eran, en realidad, "estolados".

El matiz podría no ser anecdótico. Según A. M. Canto, los "estolados" a los que se refiere Estrabón, casi romanos pero sin serlo todavía, serían los ciudadanos de derecho latino que durante los siglos II y I a.

su modo de vida a la civilización y a la manera itálica en su vestimenta togada (estos son los celtíberos y los que habitan en las proximidades del Íber a una y otra orilla hasta las regiones situadas junto al mar)" (trad. J. Gómez Espelosín, Madrid, 2006). 5 DC 46.55.5. 
C. comenzaron a proliferar en las provincias hispanas. La susodicha "estola" (casi una toga pero sin serlo, podríamos decir) actuaría así como marca distintiva del estatus jurídico intermedio de estos individuos, como "la muestra visible de su «obediencia» y «pacto» con Roma" (Canto 2001: 466).

No muy lejos de esta postura se sitúa en el fondo la interpretación de P. Le Roux, pese a que el francés aceptó la inserción del adjetivo $\tau$ o $\gamma \tilde{\alpha} \tau o$ en ambos pasajes. Según Le Roux, las menciones estrabonianas a los togados hispanos van más allá de un mero comentario pintoresco, pues el geógrafo de Amasia las ofrece como indicio de un proceso de transformación que ya estaba en marcha. La toga, según él, materializaba unos nuevos valores culturales y políticos, que no estaban fijados a priori ni eran homogéneos pero que concordaban con eso que podríamos llamar Romanitas y reivindicaban para sí los mores romanos. Expresaba, por así decirlo, la voluntad de sus usuarios de identificarse con la nueva realidad romana, renunciando, o siquiera arrumbando, sus antiguas formas de autorrepresentación (Le Roux 1995: 8-11). Es por ello, concluye el autor, que la presencia de togados es factible solo en comunidades jurídicamente promocionadas, pues era ese marco el que incentivaría a las elites locales a tomar semejante determinación respecto de su vestimenta (Le Roux 1995: 14-16).

Partiendo de distintos postulados, en definitiva, ambos autores coinciden en valorar el uso de la estola/ toga como el atributo externo de unas comunidades locales inmersas ya en un profundo proceso de transformación que a no tardar desembocaría en su asimilación definitiva en el universo romano. Otro tanto, aunque de forma más matizada, defiende G. Cruz Andreotti (2002-2003: 48-49; 2007: 262-264), quien insiste en que la prenda (o más bien las referencias estrabonianas sobre su uso) no tiene unas connotaciones jurídicas específicas, sino que su valor es puramente cultural, pues en el discurso del geógrafo póntico el concepto "estola" se suele relacionar con realidades culturales mediterráneas que, sin ser puramente civilizadas, tampoco son bárbaras. Más centrado en la agencia indígena, aunque alcanzando conclusiones parecidas, R. Olmos (2007-2008: 194-195) retrata a unas aristocracias locales que, en el proceso de contacto y redefinición identitaria de los siglos II y I a. C., se vieron empujadas a imitar la lengua, las costumbres, la ritualidad y el modo de vestir de las elites hegemónicas (romanas), alimentando así un proceso de asimilación ya muy avanzado.

Ahora bien, desde mi punto de vista, a la hora de abordar estas dos noticias estrabonianas debemos distinguir dos problemáticas de índole diversa, una filológica y la otra ideológica. Por lo que respecta a la prime- ra, considero que el susodicho estudio de A. M. Canto demostró sobradamente que carecemos de argumentos de peso para leer "togados" donde los códices estrabonianos transcriben $\sigma \tau \mathrm{o} \lambda \tilde{\alpha} \tau$ ot. Pero debemos preguntarnos también cuál es el verdadero alcance histórico de semejante precisión terminológica. ¿Pretendía Estrabón hacer algún tipo de distingo cuando hablaba de "estolados" en vez de "togados"? Reparemos en que el geógrafo no emplea la palabra latina toga en toda su Geografía, ni tampoco el término con el que esta se suele traducir al griego, $\tau \eta ́ \beta \varepsilon v v \alpha$ (con la única posible excepción, más

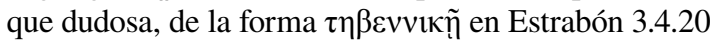
a la que ya he hecho mención). Reparemos incluso en que algunos griegos dudaban de que $\tau \eta ́ \beta \varepsilon v v \alpha$ fuera una palabra de origen helénico ${ }^{6}$, y en que muchas de nuestras fuentes griegas ni siquiera la emplean. Y fijémonos en que, como la propia A. M. Canto demuestra, hasta por lo menos el siglo II a. C. ni siquiera las fuentes latinas distinguían claramente entre "toga" y "estola". Por consiguiente, me parece que, aun aceptando que Estrabón habló en 3.2.15 (¿y en 3.4.20?) de "estolados" y no de "togados", no contamos con elementos de juicio suficientes como para aseverar que, en su descripción de las comunidades hispanas, el geógrafo de Amasia se refería a una prenda distinta de la toga-estola empleada por los romanos de época tardorrepublicana.

Consideración esta que nos lleva a la segunda problemática mencionada, la de índole ideológica. Como puede inferirse de los párrafos anteriores, buena parte de la bibliografía viene asumiendo el razonamiento de Estrabón, según el cual la toga es la materialización visible de un proceso de asimilación cultural ya muy avanzado, por el cual algunos de los pueblos hispanos convergían y se aproximaban a la romanidad. Pero esta aseveración encierra en realidad numerosas incógnitas que no han sido todavía suficientemente exploradas: ¿qué impulsaría a estas comunidades a ceñirse una prenda tan poco práctica como la toga, por muy asimiladas al mundo romano que estuviesen? ¿Realmente la portarían? ¿Quiénes de entre estas comunidades? ¿Estarían obligados a hacerlo? ¿Tendrían siquiera derecho a hacerlo según la legislación romana, dado que, según el propio Estrabón, no eran todavía ciudadanos romanos? ¿Por qué se les llamaría precisamente "togados", y no "habitantes de villae", o "comedores de garum", por ejemplo?

\section{TOGADOS EN LOS SANTUARIOS IBÉRICOS}

El tema que nos ocupa ha sido abordado casi siempre desde el punto de vista de la historia cultural roma-

\footnotetext{
${ }^{6}$ Dion. Hal. 3.61.
} 


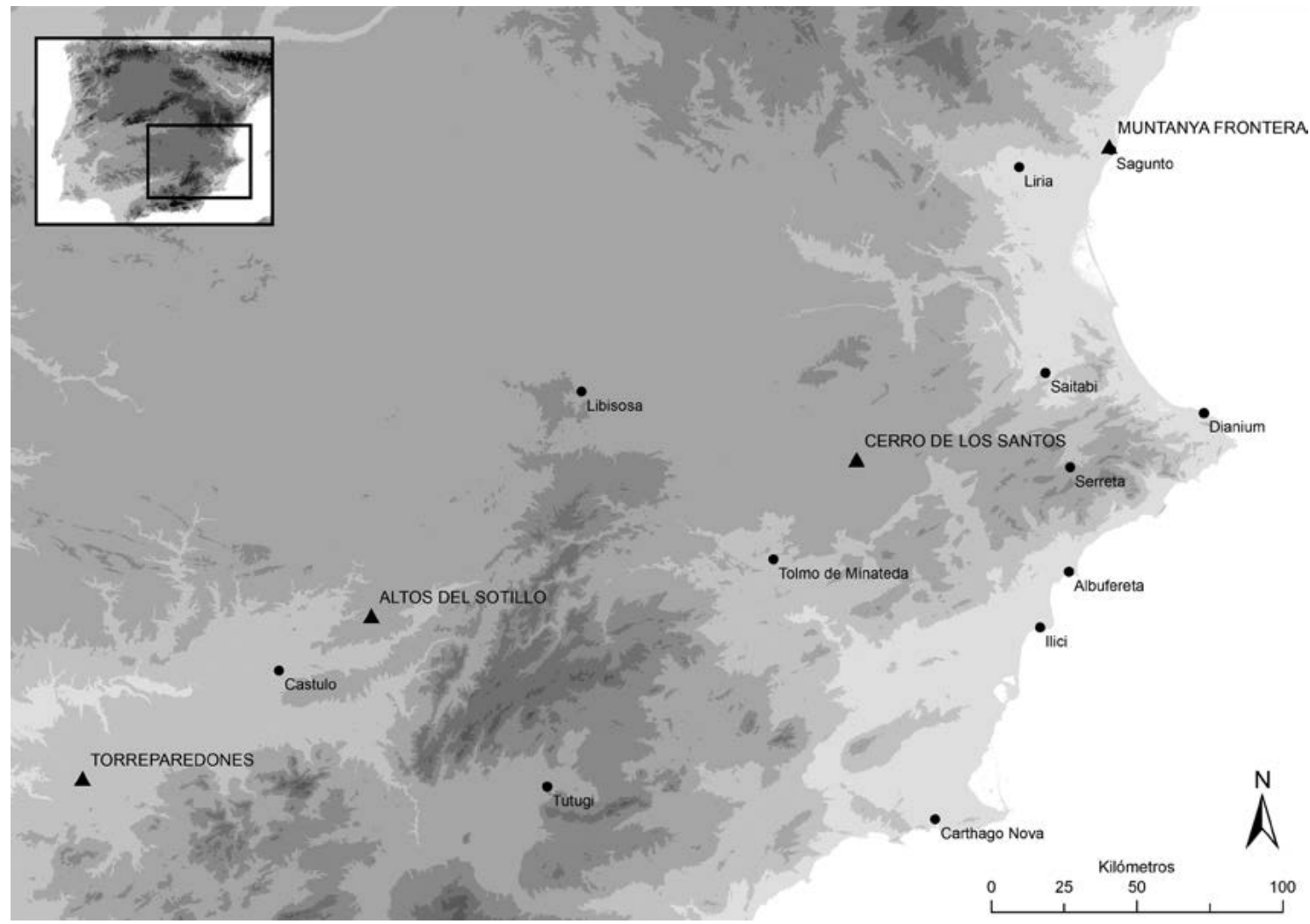

Figura 1. Principales santuarios mencionados en el texto y su contexto territorial (cartografía del autor).

na, pero, en este caso, propongo conectarlo con el análisis del registro arqueológico ibérico, centrándonos concretamente en los exvotos depositados en los santuarios extraurbanos. Y es que en toda una serie de contextos sacros de este tipo nos topamos con representaciones de varones togados fechables en torno a los siglos II y I a. C. que bien pudiéramos poner en relación, indirecta quizás, filtrada sin duda, con los comentarios estrabonianos antes mencionados (Fig. 1).

Tal es el caso del Cerro de los Santos (Montealegre del Castillo, Albacete). Hablo de un santuario extraurbano, alejado de los principales núcleos de población de la época pero ubicado en un pequeño altozano que dominaba la Vía Heraklea, principal vector de comunicaciones entre el sureste costero, la Meseta y la Alta Andalucía. La divinidad local, posiblemente una diosa relacionada con los ganados que en época romana respondería al nombre de Palas, recibió culto en este ámbito sacro al aire libre desde al menos el siglo III a. C., por parte de unos devotos que, provenientes de toda la región, viajaban al lugar para ofrecer libaciones y exvotos y participar en rituales de comensalidad. Los más poderosos de entre ellos, además, depositaron en el santuario exvotos que no eran sino representa- ciones en piedra de sí mismos, y que perpetuaban su presencia ante la divinidad al tiempo que construían (y negociaban competitivamente) su estatus en su sociedad (Chapa 1984; Ruiz Bremón 1989; García Cardiel 2015).

Hasta nosotros han llegado centenares de estos exvotos escultóricos, fechables con bastante probabilidad entre los siglos III y I a. C. Pero fijémonos en algunos de los fragmentos escultóricos más tardíos, parte de los cuales, debido a su singularidad dentro del rico corpus escultórico del Cerro, atrajeron desde muy pronto la atención de la bibliografía (vid., por ejemplo, García y Bellido 1943: 84-86; Balil 1960). Me refiero fundamentalmente a cuatro torsos masculinos revestidos de un atuendo muy distinto al de los demás varones representados en el santuario: una toga ceñida recogida sobre ambos hombros que les envuelve el brazo derecho hasta la altura de la muñeca, bajo la que emerge una mano que sujeta firmemente los pliegues del paño?

${ }^{7} \mathrm{~N}^{\mathrm{o}}$ inv. 3512, 7641, 7651 y 7652 del Museo Arqueológico Nacional. Habría que incluir también entre estos torsos el togado con bulla desaparecido poco después del inicio de las excavaciones en el yacimiento, y que conocemos solo a través de una 


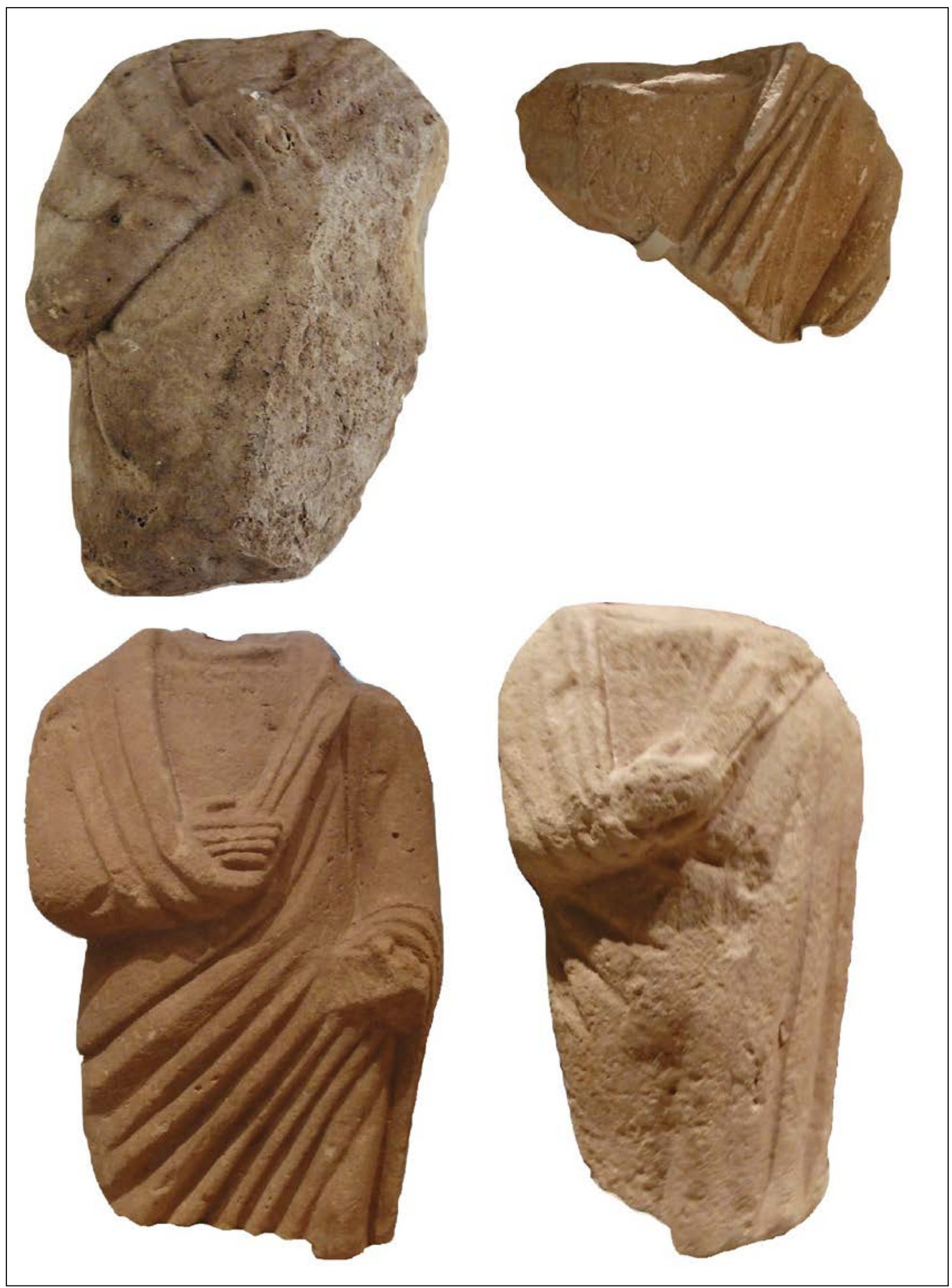

Figura 2. Exvotos escultóricos del Cerro de los Santos, Museo Arqueológico Nacional (fotografías del autor). 
Hemos de mencionar igualmente al menos tres cabezas masculinas que, rompiendo con los cánones ibéricos tradicionales, se cubren con un pesado paño, al estilo de los capitibus velatis $^{8}$. Y aludiremos también a un puñado de fragmentos de manos, pies y paños que diversos autores han interpretado como pertenecientes a nuevos togados (Ruiz Bremón 1986: 71-73; 1987-1988: 335-340; Noguera 1994: 96-144), si bien la identificación de estos últimos me parece algo menos segura. Es de reseñar, en todo caso, que tres de los cuatro torsos mencionados presentan una inscripción en la que se refleja un nombre propio; una de ellas, en escritura latina, identifica a su portador como Lucio Licinio", beneficiario por ende de la ciudadanía romana o latina (Ruano 1988: 260); los otros dos, en cambio, tienen nombres ibéricos, referidos en signario ibérico meridional $^{10}$ (Rodríguez Ramos 2002; Velaza 2007: 277 280; vid. también Izquierdo y Velaza 2007); dato este ciertamente singular para dos varones que se hacen representar revestidos de sus respectivas togas (Fig. 2).

De cualquier forma, los togados del Cerro, de tamaño algo menor que el natural, presentan significativas analogías estilísticas con los numerosos exvotos de terracota con representaciones de togados amortizados en ciertos santuarios centroitálicos entre los siglos IV y II a. C., lo que, unido a las dinámicas históricas del sureste meseteño y al registro arqueológico del propio santuario, llevó en su momento a J. M. Noguera (1994: 109-118) a proponer para ellos una datación de mediados del siglo II a. C. Tal cronología es algo más antigua que la fecha tradicionalmente asignada a todas estas esculturas togadas, entre mediados del siglo I a. C. y el cambio de Era (García y Bellido 1943: 86; Ruiz Bremón 1986: 69 y 73). Tanto una propuesta como la otra, desde mi punto de vista, resultarían coherentes con los últimos estudios sobre los materiales documentados en el santuario, según los cuales a finales del siglo I a. C. la amortización de ofrendas (incluyendo los exvotos antropomorfos) decae en la ladera norte del Cerro, dando paso a un tipo de culto distinto, focalizado en el templo de estilo itálico que se erige en su cúspide y en las dependencias construidas a sus pies, junto a la vía (García Cardiel 2015; Brotons y Ramallo 2017).

Los togados del santuario del Cerro de los Santos, en cualquier caso, encuentran también un buen paralelo (salvo por las dimensiones) entre los exvotos del san-

fotografía; pese a su singularidad, el hecho de que la pieza fuera documentada antes del inicio de las falsificaciones parece una prueba de su autenticidad; Noguera 1994: n. 453.

${ }^{8} \mathrm{~N}^{\circ}$ inv. 7532 del Museo Arqueológico Nacional, 4303 del Museo de Albacete y CS-S-33 del Museo Municipal Cayetano de Mergelina de Yecla.

9 CIL II, supp. 514*. Vid. Díaz 2008: C55.

${ }^{10}$ MLH III G14.01 y G.14.02. Vid. De Hoz 2011: 352-353. tuario de Torreparedones (Castro del Río-Baena, Córdoba). En efecto, entre el nutrido depósito votivo amortizado en este templo suburbano (levantado frente al oppidum homónimo a comienzos del siglo II a. C., restructurado en época de Claudio y abandonado ya cerca del siglo III d. C.: Morena 2017: 50-65), destaca un único exvoto fragmentado de piedra de $13,7 \mathrm{~cm}$ de altura, conservado en una colección particular y que representa un torso recubierto por una toga cuyos pliegues cubren ambos hombros y envuelven el brazo derecho, cruzando en bandolera sobre el pecho y dejando asomar tan solo la mano que aferra el extremo de la prenda (Morena 1989: lám. XXVI; Fernández Castro y Cunliffe 2002: fig. 84). La pieza data con toda probabilidad de la primera fase del santuario, entre los siglos II y I a. C., y, como les sucedía a los togados del Cerro de los Santos, se diferencia del resto de los exvotos antropomorfos varoniles únicamente en su vestimenta, pero no en su tipo de labra, tamaño o actitud ritual (Fig. 3).

Quizá menos conocido, aunque igualmente significativo, es el togado del santuario de Los Altos del Sotillo (Castellar, Jaén). Nuevamente hablamos de un santuario extraurbano, situado en este caso en la frontera del territorio controlado por Cástulo desde finales del s. IV a. C., al que los devotos de la región acudirían periódicamente para llevar a cabo toda una serie de prácticas rituales, entre las que se encontraba la consagración de pequeños exvotos, en este caso de bronce, que les representaban a ellos mismos. Sin embargo, en los Altos del Sotillo se aprecia bien una cesura en la práctica ritual coincidente

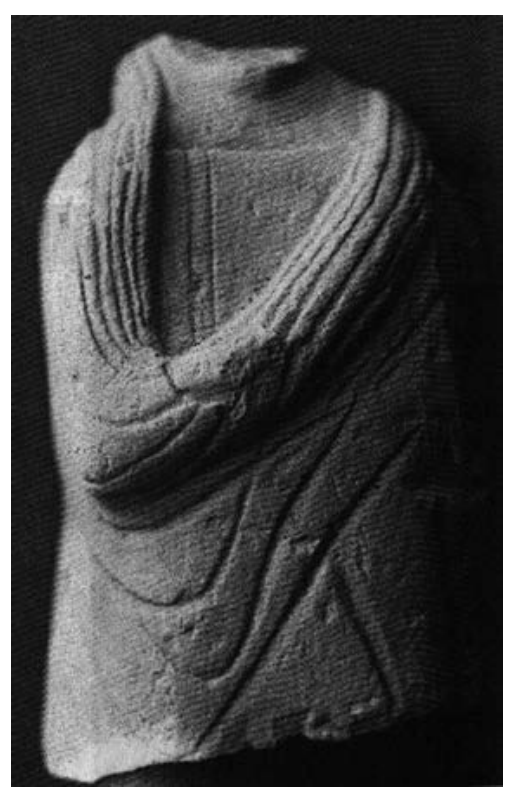

Figura 3. Exvoto escultórico de Torreparedones (colección privada) (tomado de Morena 1989: lám. XXVI). 


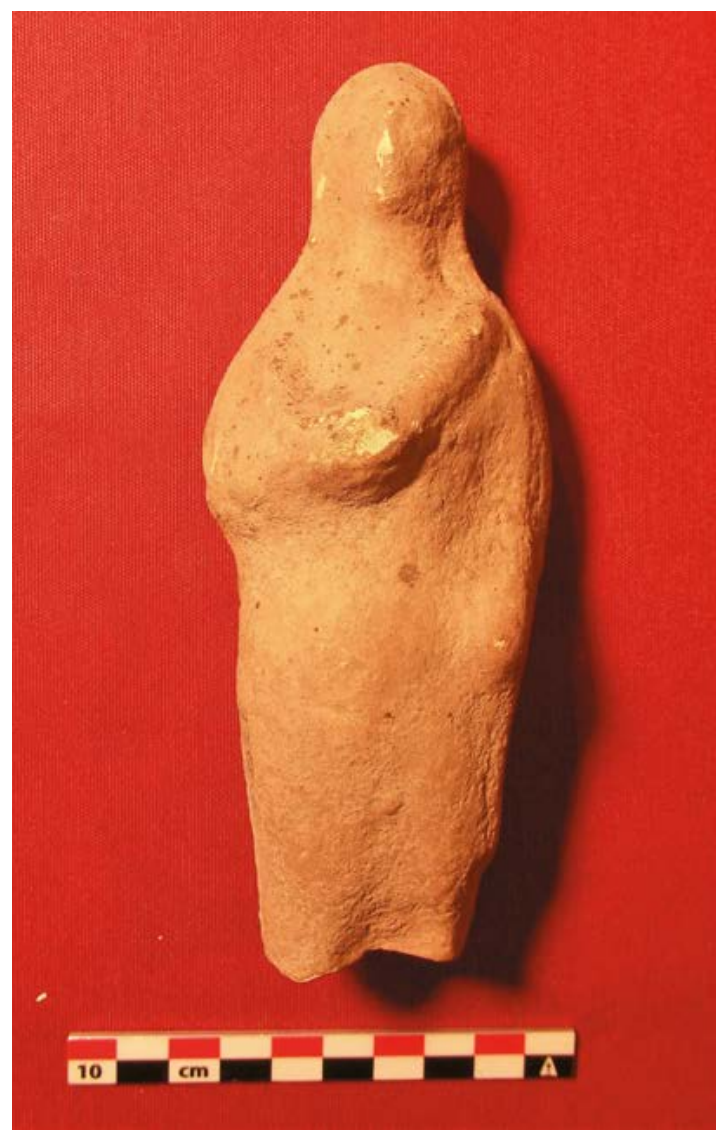

Figura 4. Exvoto de terracota de los Altos del Sotillo (Museo Arqueológico Nacional) (fotografía del autor).

con la conquista romana de la región y la consiguiente desestructuración del territorio castulonense: a partir de comienzos del siglo II a. C., toda esa miríada de exvotos de bronce singulares fue sustituida por exvotos de terracota fabricados en serie y que representaban ora a los devotos, ora a divinidades como Minerva, Mercurio y Venus (Rueda 2011: 111-116). Pues bien, entre estas últimas representaciones de devotos coincidentes con la fase postrera de uso del santuario tenemos documentado un pequeño togado de terracota del tipo tardorrepublicano, con la cabeza velada por el extremo de la prenda (Blech 1999: 159 y 173) (Fig. 4).

Por último, merece la pena mencionar un santuario extraurbano mucho menos estudiado y que todavía no ha sido objeto de excavaciones arqueológicas sistemáticas, sito en la periferia del solar saguntino: Muntanya Frontera (Sagunto, Valencia). En época augustea, parece ser que se erigieron sobre este cerro varios altares grabados con inscripciones latinas que honraban a Liber Pater, teónimo que posiblemente era el resultado de la interpretatio romana de la deidad local
(Civera 2014-2015: 155-158). Seguramente anteriores en el tiempo, datables quizás entre los siglos II y I a. C. (Aranegui et alii 2018: 460), son los nueve exvotos antropomorfos masculinos en bronce, ingresados en 2006 en el Museo de Sagunto a través de una donación particular. Tres de ellos figuran a otras tantas divinidades desnudas (posiblemente Hércules, Júpiter y, acaso, una deidad local), pero los otros seis representan a devotos varones, portadores todos ellos de la consabida toga tardorrepublicana (Aranegui et alii 2018: 457-468). La aparición de estos exvotos de bronce es llamativa, pues técnicamente se asemejan mucho a las ofrendas habituales en los santuarios jienenses y murcianos, pero no encuentran correlato alguno en la región valenciana. Pero es que además los exvotos de Muntanya Frontera son los únicos en todo el mundo ibérico que, aparentemente, se sustentaban sobre pequeños pedestales cúbicos de caliza, igualmente localizados en el enclave y preparados para recibir las espigas que rematan los pies de estas curiosas estatuillas (Aranegui et alii 2018: 458-459). Diez de estos pedestales, por cierto, contienen inscripciones ibéricas, al menos cuatro de las cuales aludían a nombres propios $^{11}$; con toda probabilidad los nombres, sorprendentemente ibéricos, de los devotos togados cuyas efigies en bronce se insertarían sobre ellos (Fig. 5).

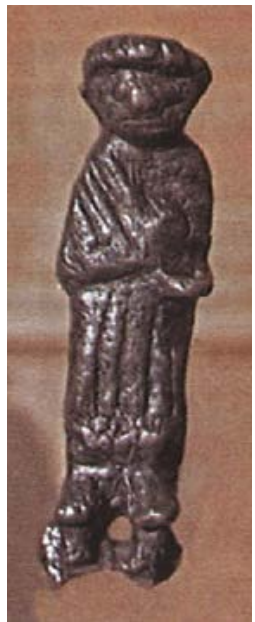

Figura 5. Exvoto de bronce de Muntanya Frontera (Museo Histórico de Sagunto) (tomado de Aranegui et alii 2018: 465).

Las analogías estilísticas entre todas estas piezas y los togados itálicos tardorrepublicanos, junto con la presencia de las propias togas y su fuerte carga simbólica, han llevado en ocasiones a considerarlas muestras de un "arte romano provincial", imitación imperfecta, tosca y periférica de una plástica que en Italia alcanzó sus más altas cotas de pureza (vid., por ejem-

\footnotetext{
${ }^{11}$ MLH F11. Vid. Simón 2012.
} 
plo, León 1981: 196; Ruiz Bremón 1986: 77). Sin embargo, semejante línea de lectura es, al menos desde mi punto de vista, problemática. Si devolvemos a su contexto (a lo que conocemos de su contexto) a todos los togados y capitibus velatis del Cerro de los Santos, por ejemplo, comprenderemos al punto que responden a idénticas dinámicas y necesidades que el resto de los centenares de exvotos escultóricos antropomorfos que durante tres siglos fueron consagrados en el lugar. Otro tanto sucede en Torreparedones y, a su manera, en la última fase de frecuentación de los Altos del Sotillo. A pesar del nuevo atuendo con el que se adornaron todos estos personajes, su postura, contexto y gesto ritual no muestran cesura alguna respecto del resto de los varones y mujeres representados en sus respectivos santuarios. Es posible que estas piezas incorporaran nuevas modas, pero las adaptaron e interpretaron poniéndolas al servicio de un lenguaje propio, el mismo que llevaba operativo en las sociedades que visitaban estos lugares desde varias generaciones atrás (Ramallo et alii 1998: 45-49; Noguera y Rodríguez Oliva 2008: 382). El mismo que, aparentemente, terminó imponiéndose con el tiempo, al menos en contextos sacros como el de Muntanya Frontera. La aparición de inscripciones sobre algunos de los ejemplares del Cerro de los Santos y de Muntanya Frontera, de hecho, no hace sino redundar en la misma idea: excepción hecha del famoso Lucio Licinio del Cerro de los Santos, nos encontramos ante individuos con estructura onomástica peregrina que, por lo que parece, no tenían inconveniente en acudir a sus santuarios tradicionales exhibiendo una toga sobre su cuerpo.

Es por todo ello por lo que, en lugar de hablar de una imitación imperfecta de los supuestos prototipos itálicos, en los últimos años se ha insistido en el carácter "bilingüe", "mestizo" o "híbrido" de estas esculturas togadas (Jiménez 2011: 107; Ramallo y Brotons 2014: 38-39), enfatizando precisamente su naturaleza mixta, propia de una cultura iberorromana que ya no era ni ibérica ni romana, sino otra cosa distinta. Con entidad propia.

\section{EL ESTATUTO JURÍDICO DE LOS TOGADOS HISPANOS}

La consideración bilingüe, mestiza o híbrida de estas esculturas, sin embargo, no apura toda su problemática. Atestigua, bien es cierto, un profundo y sistemático contacto entre dos sistemas culturales que en origen eran diversos, y documenta la génesis de unas estructuras nuevas, híbridas, diferentes a las anteriores y que responden a un lenguaje propio, coherente con la nueva situación colonial. Permite superar, pues, el viejo paradigma que describía todas estas piezas como imitaciones imperfectas de unos cánones metropolitanos, propios de unas sociedades periféricas solo parcialmente aculturadas. Pero, como ocurre en ocasiones al aplicar este tipo de conceptos postcoloniales, la hibridación no termina de explicar por qué surgieron concretamente esas nuevas realidades culturales, en virtud de qué desequilibrios históricos y como respuesta a qué agendas coyunturales.

Estoy asumiendo aquí, adviértase, una de las críticas más frecuentes a la teoría postcolonial, teoría de la que pese a todo no dejo de declararme deudor. Se ha señalado con frecuencia, y posiblemente con razón, que las interpretaciones en torno al concepto de "hibridación" tienden a ser ahistóricas (Ahmad 1995; Prabhu 2007), pues suelen centrarse en el análisis de ciertos fenómenos culturales concretos, considerándolos constructos finales surgidos a partir de la simbiosis de sistemas culturales previos sin considerar que 1) no existe en realidad ningún sistema cultural "puro", sino que todos son, en última instancia, híbridos; y 2) el análisis histórico no ha de concluir con la documentación del objeto, costumbre o ritual híbrido, sino que debe partir de la constatación de dicha hibridación para discriminar las dinámicas históricas que motivaron su surgimiento.

Nuestras esculturas de togados son, en este sentido, un excelente campo de pruebas para ponderar los límites del paradigma de la hibridación. Para empezar, su conceptualización como productos culturales híbridos iberorromanos presupone, siquiera de manera implícita, que en algún momento hubo unas culturas prístinas "ibérica" y "romana", algo difícil de aceptar en un "mundo pequeño" e interconectado como era el Mediterráneo antiguo (Malkin 2011). Pero reparemos además, y esto es lo más significativo, en que la nueva consideración "híbrida" de estas esculturas nos lleva en realidad, en cierta medida, al punto de partida: si las antiguas lecturas difusionistas defendían que los togados del Cerro de los Santos, representaciones imperfectas propias de un arte romano provincial, aludían a los individuos más romanizados de su comunidad (Ruiz Bremón 1986: 75), la conclusión histórica de muchas de las nuevas lecturas que inciden en el carácter híbrido de estas esculturas no es muy diferente: las mismas pudieron pertenecer, se sostiene, a magnates romanos o itálicos residentes en Hispania o bien a sus clientes y aliados más fieles (Rodà 1998: 266; Ramallo y Brotons 2014: 38-39).

Mas nos topamos aquí con una paradoja que en muchas ocasiones se ha pasado por alto ${ }^{12}$ : aunque ciertamente los togados iberorromanos, notorias realiza-

\footnotetext{
${ }^{12}$ Aunque con notorias excepciones, como A. M. Canto 2001.
} 
ciones culturales híbridas, evidencian las altas cotas de síntesis cultural que hubieron de caracterizar a la sociedad hispana tardorrepublicana, ¿es que acaso los integrantes de esa sociedad híbrida, casi romanos pero no del todo en palabras de Estrabón, tenían derecho a vestir la toga?

La cuestión no es baladí, pues la toga suele considerarse la prenda "nacional" romana por excelencia (Niemeyer 1968: 40; Goette 1990; Baena 1993: 165 166; 1996: 31; Edmonson 2008: 22-23; Rothe 2009: 40). El propio Virgilio denominó gens togata al pueblo romano $^{13}$, y sabemos que Augusto decretó que todo ciudadano romano debía portar la toga para poder entrar en el Foro ${ }^{14}$ y asistir al teatro ${ }^{15}$, obligación de la que un siglo después Plinio el Joven se quejaba con hastío en sus cartas ${ }^{16}$. Según cuenta Suetonio, en cierta ocasión Claudio presidió un juicio en el que se acusaba a un hombre de haber usurpado la ciudadanía romana, proceso durante el cual el emperador dictaminó que el sospechoso había de ponerse o quitarse la toga según hablara la defensa o la acusación ${ }^{17}$. En la misma línea, Plinio menciona una ley que prohibía continuar portando la toga a los ciudadanos romanos condenados al exilio ${ }^{18}$. En un pasaje ciertamente singular en el que Tácito describe los afanes de Agrícola para "romanizar" Britania, el autor menciona la toga, como vimos que hizo Estrabón, como uno de los principales indicadores del éxito aculturador ${ }^{19}$. La toga se entendía, en definitiva, como una prenda de fuertes connotaciones identitarias, a través de la cual se expresaban la pertenencia a la comunidad de intereses romana y la conformidad con el mos maiorum. Es más, ciertos colores, ribetes y adornos de la prenda, como es bien sabido, servían para visualizar el estatus concreto de cada ciudadano (Edmonson 2008: 21-27; Rothfus 2010; Larsson Lovén 2014: 430).

Ahora bien, más allá de la innegable carga simbólica e identitaria de la toga para los ciudadanos romanos, me parece mucho más complejo atribuirle un valor jurídico concreto y privativo, como en muchas ocasiones ha dado por sentado la historiografía, basándose fundamentalmente en los citados testimonios de Suetonio y Plinio el Joven (vid., por ejemplo, Edmonson 2008: 22; Rothe 2009: 26 y 40). De las mencionadas noticias parece desprenderse, en efecto, que los ciudadanos romanos condenados eran despojados de la toga como parte de su castigo, pero de ello no

\footnotetext{
13 Verg., Aen. 1.282.

14 Suet., Aug. 40.5.

15 Suet., Aug. 44.2.

16 Plin., Ep. 5.6.45.

17 Suet., Claud. 15.2 .

18 Plin., Ep. 4.11.3.

19 Tac., Agr. 21.3.
}

puede deducirse, desde mi punto de vista, que todos los ciudadanos romanos la portaran, ni tampoco que tuvieran prohibido hacerlo quienes no eran ciudadanos romanos. Sobre la primera de estas cuestiones, resultan esclarecedores los testimonios de Marcial y Juvenal, cuyas sátiras no cejan de insistir en el poco entusiasmo con el que la toga era empleada en su época en Italia o en Hispania, bien por considerarla un símbolo de opresión o por su escasa practicidad (Baena 1993: 171-172; Vout 1996; George 2008). El propio Suetonio narra un episodio en el que Augusto, el mismo gobernante que había impuesto el uso de la prenda como condicionante para participar en los actos públicos romanos, durante una velada jubilosa en la bahía de Nápoles distribuyó togas entre sus amigos griegos y pallia entre sus camaradas itálicos, a condición de que durante el convite los primeros hablaran latín y los segundos, griego ${ }^{20}$. Implicando así que vestimentas e idiomas eran criterios identitarios intercambiables según el contexto y las necesidades e intereses de cada cual, gracias al middle ground generado por el recién instaurado Imperio (Wallace-Hadrill 2012: 369-371).

En cuanto a la segunda de las cuestiones aludidas, el supuesto veto a que los no ciudadanos usaran toga, reparemos en que, pese a los episodios mencionados, no parece que se llegara a dictar nunca una ley explícita al respecto (Goette 1990: 2). Al fin y al cabo, si bien a los ciudadanos condenados al exilio se les prohibía continuar vistiendo la toga, también se les vetaba el disfrute del agua y el fuego en tierras itálicas, lo que no significaba que quienes no eran ciudadanos tuvieran prohibido abastecerse de tan vitales elementos mientras residieran en la península itálica.

Es más, incluso si aceptáramos que el uso de la toga llegó a ser obligatorio y privativo de los ciudadanos romanos en época imperial, difícilmente podríamos extrapolar esa regulación a fechas anteriores a Augusto (Rothfus 2010: 442, n. 42). Ninguna de estas referencias sobre el empleo reglamentado de la toga es anterior al Principado. Y repárese en que, si Augusto obligó a sus conciudadanos a vestir la toga en determinados actos públicos, fue porque, según narra el propio Suetonio, se mostró escandalizado de que estos no estuvieran habituados a hacerlo ${ }^{21}$. Su medida debe encuadrarse, pues, en la "reforma" de las costumbres impulsada por el Princeps tras las guerras civiles, de signo pretendidamente tradicionalista pero que sabemos tuvo también mucho de reformulación del mos maiorum. Una reformulación ideológica que, de hecho, podría haberse visto plasmada en la propia iconografía de las togas: fijémonos en que, hacia el cambio de Era,

\footnotetext{
${ }^{20}$ Suet., Aug. 98.3.

21 Suet., Aug. 40.5. Vid. también App. BC. 2.17.120.
} 
las togas dejan de ser unos modestos mantos ceñidos en torno al torso del varón que envuelven precariamente su brazo derecho (enfatizando posiblemente la circunspección y autocontrol acordes con los valores republicanos) y se convierten en ostentosas prendas anchas y repletas de pliegues que subrayan las proporciones hercúleas de su portador, acentuando su prosperidad, fortaleza y virilidad (Davies 2005; Rothfus 2010: 442-450; Larrson Lovén 2014: 431).

Nuestras fuentes literarias referidas a las relaciones diplomáticas que Roma mantuvo con los jerarcas de sus estados vecinos entre finales del siglo III y el siglo II a. C., de hecho, son especialmente reveladoras del viraje semántico de la toga. Así, sabemos que, cuando el rey númida Sífax envió en 210 a. C. embajadores a Roma para suscribir una alianza contra Cartago, el Senado le agasajó regalándole una silla de marfil, una pátera de oro, una túnica púrpura y una toga ${ }^{22}$; cuando en 203 a. C. Escipión proclamó rey de los númidas a Masinisa en lugar de a Sífax, le honró con una corona de oro, una pátera de oro, una silla curul, un cetro de marfil, una túnica y una toga ${ }^{23}$; el propio Masinisa recibió en el año 200 a. C. del Senado romano vasos de oro y plata, un cetro de marfil, una túnica palmeada, un manto púrpura y una nueva toga praetexta ${ }^{24}$. Si los tronos, los objetos de oro y los mantos púrpuras subrayaban la condición real de estos personajes, el ofrecimiento oficial de togas a unos individuos que, evidentemente, no eran ciudadanos romanos, buscaba enfatizar los vínculos de amicitia entablados con ellos. Lección esta que, de hecho, los propios jerarcas aliados de Roma no tardaron en hacer suya: de Antíoco IV de Siria se decía que acostumbraba a despojarse de sus atuendos reales y vestir la toga, circulando modestamente por el ágora "a la usanza romana" 25 . Aunque más revelador todavía es el caso del rey Prusias II de Bitinia, que hacia 167 a. C. acudió a Roma para solicitar ayuda militar, ocasión en la que, tratando de congraciarse con el Senado, recorrió las calles de la urbs portando una sencilla toga y diciéndose liberto de los romanos ${ }^{26}$.

Regresando a tierras hispanas y pasando ya al siglo I a. C., debo hacer referencia al conflicto sertoriano, pues es bien sabido que, durante la guerra, Sertorio creó en Osca una escuela para afianzar la cultura griega y romana entre los hijos de sus aliados hispanos, inculcándoles valores apropiados a quienes estaban llamados a convertirse en los futuros gobernantes de

\footnotetext{
22 Liv. 27.4.5-10

23 Liv. $30.15 .11-14$.

24 Liv. 31.10.11-12.

25 Plb. 26, frag. 1.1-6 (=Aten. 5.193d).

26 Plb. 30, frag. 18.
}

sus comunidades locales hispanas pero, al tiempo, garantizando con su presencia en Osca la fidelidad de sus progenitores en el frente. La medida, al menos en un principio, no fue mal acogida por unos orgullosos padres que, en palabras de Plutarco, "disfrutaban extraordinariamente al ver a sus hijos con togas orladas de púrpura ir y venir a las escuelas con mucho orden" 27.

La evidencia literaria indica, pues, que al menos en época republicana el empleo de la toga no estaba reservado a los ciudadanos romanos o itálicos, sino que también podía ser portada por aquellos individuos que se erigieran en valedores de la agenda romana en sus respectivas comunidades (y que, por ende, en un momento dado pudieran ser respaldados por el poder romano si así lo requerían). La toga materializaba, de alguna manera, la condición de amicus populi Roma$n i$ de sus poseedores. Valor este que parece en consonancia, de hecho, con las diversas referencias a la llamada formula togatorum, el listado que confeccionaban los romanos de las contribuciones militares anuales de sus aliados itálicos (Baronowski 1984; Lo Cascio 1991-1994); unos aliados que no eran ciudadanos romanos, evidentemente, pero que, en su condición de aliados de la causa romana, eran conocidos colectivamente como togati.

Sirva este largo excurso, en definitiva, para refutar la idea de que las esculturas togadas de los santuarios ibéricos hubieron de representar necesariamente a ciudadanos romanos o latinos, como tantas veces se ha asumido (vid., por ejemplo, Baena 1993: 168-169, 1996: 31; Canto 2001: 466-473; Melchor 2009: 393; Rodríguez Gutiérrez 2012: 121-122; Carroll 2015: 154155). Resulta indudable que los personajes que optaban por hacerse retratar en los lugares de culto con esta prenda tan característica deseaban subrayar su cercanía al poder provincial romano, y no pretendo negar que algunos de estos individuos sí pudieron ser ciudadanos $^{28}$, pero me parece que no contamos con argumentos suficientes como para avalar la ciudadanía de todos ellos. La literatura histórica referida al período avala suficientemente que los individuos sin derecho alguno de ciudadanía también podían vestirla.

Lo que a su vez contribuye a explicar, en mi opinión, que tengamos documentadas tan pocas escultu-

\footnotetext{
${ }^{27}$ Plut. Sert. 14 (trad. de J. Bergua, S. Bueno y J. M. Guzmán para Gredos, Madrid, 2007).

${ }_{28}$ El caso de Lucio Licinio, el varón que se hizo representar en el Cerro de los Santos vistiendo la toga y con su nombre grabado, es paradigmático en este sentido: Noguera 1994: 118121. Vid., contra, Curchin 1990: 85-86 y 89, para quien, en la línea propuesta por E. Badian (1958: 256), la estructura onomástica romana podía ser, como la propia toga, usurpada por unas elites locales deseosas de convertirse en ciudadanos de pleno derecho.
} 
ras togadas en contextos hispanos tardorrepublicanos, circunstancia esta que sería extraña si la toga fuera la vestimenta adecuada a los ciudadanos romanos o latinos, habida cuenta del gran desarrollo del que, según investigaciones recientes, gozó el estatuto latino en la Hispania tardorrepublicana (García Fernández 2009). Paradoja que se repite, añadiría, en otros contextos provinciales. Bien estudiado en este sentido ha sido el caso de los tréveros, donde la proporción de retratos togados en relación con las representaciones de otro tipo de atuendos se dispara en el siglo I d. C., pero luego decae vertiginosamente hasta convertirse en anecdótica a partir del siglo II d. C., evidenciando que la correlación entre el uso de la toga y la extensión de la ciudadanía no era mecánica (Rothe 2009: 49-53). $\mathrm{Ni}$ siquiera, adviértase, en época imperial.

\section{NEGOCIACIÓN IDENTITARIA Y COMPETICIÓN SOCIAL: HIBRIDACIÓN Y MÍMESIS EN LOS TOGADOS IBERORROMANOS}

Solventada la cuestión de la supuesta ciudadanía de nuestros togados iberorromanos, empero, hemos de volver al interrogante que nos planteábamos al comienzo del apartado anterior: ¿por qué, en un panorama de creciente síntesis cultural entre lo ibero y lo romano, se produjeron en distintos santuarios estas realizaciones híbridas concretas? ¿Y por qué, añadamos ahora, fueron casi siempre minoritarias?

Fijémonos, en primer lugar, en los contextos de aparición y exclusión de nuestras piezas. Las esculturas togadas iberorromanas, señala con mucho acierto A. Jiménez (2011: 117), "made sense in the context of the province by means of a simultaneous relational reference to what they were not (...) and to what they were similar to". Se parecen, sin duda, a las terracotas de los santuarios centroitálicos mencionadas páginas atrás, pero también a los togados tardorrepublicanos erigidos en las ciudades y necrópolis de la península itálica. Y todavía guardan una relación más estrecha con los infrecuentes togados tardorrepublicanos documentados en algunos de los municipios y colonias romanos en Hispania, como Barcino, Tarraco, Lucentum o $\mathrm{Urso}^{29}$. Se parecen a estos togados romanos, en efecto, pero, parafraseando las palabras de A. Jiménez, no lo son. No lo son porque, en realidad, más allá de las apariencias estéticas, responden a unas dinámicas sociopolíticas totalmente distintas.

29 Para un recuento en su momento exhaustivo, vid. Canto 2001: 466-473. Sobre el togado de Lucentum, vid. Olcina 2009: 118 .
En este sentido, me parece sumamente significativa una peculiaridad que ya percibió en su momento J. M. Noguera (1994: 206-207; vid. también Jiménez 2011: 106-107), pero sobre la que creo que todavía no se ha reflexionado lo suficiente: al contrario de lo que suele suceder con los togados republicanos (y de lo que sucederá ya más claramente en épocas imperiales), nuestros togados iberorromanos no aparecen en contextos urbanos ni necropolitanos, sino que se documentan solo en espacios sacros. En cambio, encuentro muy llamativa la ausencia de representaciones de togados entre la prolija iconografía vascular de asentamientos como la Alcudia de Elche o el Tolmo de Minateda y sus respectivos hinterlands, cuyos alfares decoraron sus cerámicas con toda una miríada de personajes (héroes, ancestros, aristócratas) vestidos al modo "tradicional" local. Pese a las concomitancias que las cerámicas más tardías de la Alcudia de Elche presentan con la llamada cerámica bracarense, por ejemplo, no encontramos en el enclave contestano nada parecido al togado que, sosteniendo una palma y acompañado de una mujer desnuda, aparece en un galbo conservado en el Museu D. Diogo de Sousa y datado entre finales del siglo I y comienzos del II d. C. (Ronda y Tendero 2014: 209).

También parece sugestivo el carácter minoritario de todos estos togados en relación con sus respectivos contextos inmediatos. Solo unos pocos de los exvotos antropomorfos masculinos del Cerro de los Santos, y solo uno de Torreparedones y otro de los Altos del Sotillo, revistieron la toga. Semejante exclusividad no se explica simplemente aludiendo al carácter híbrido de las estructuras culturales que dieron lugar a estas esculturas, ni tampoco juzgando que quienes no optaron por la toga eran más refractarios al cambio (Ruiz Bremón 1989: 180) o estaban más alejados de las estructuras romanas de poder (Rodà 1998: 266). No olvidemos, al fin y al cabo, que todo atuendo es un constructo cultural semánticamente connotado, por lo que ninguno es inocente (Vout 1996: 210). De la misma manera que unos pocos personajes de cada comunidad optaron por hacerse representar en sus santuarios portando la toga, otros, la mayoría, decidieron hacer lo contrario. Tarea nuestra es discernir las motivaciones de unos y otros.

Desembocamos así, por fin, en la cuestión de las motivaciones. Una cuestión que, como veíamos al comienzo de estas páginas, deviene central para estudiar los procesos de negociación e integración cultural a escala regional o local. ¿Qué llevó a determinados sujetos a hacerse figurar en todos estos santuarios "ibéricos" vistiendo la toga "romana", cuando, salvo en el caso de la Muntanya Frontera, la mayoría de los miembros de sus respectivas sociedades optó por con- 
tinuar representándose con sus vestimentas tradicionales hasta el cambio de Era?

Para proponer una respuesta a semejante interrogante, es necesario introducir aquí otro concepto postcolonial, avanzado, hace ya más de dos décadas, por H. Bhabha (1994: 86). Me refiero a la mímesis, un fenómeno propio de los escenarios coloniales en virtud del cual ciertos actores locales se esfuerzan por asimilarse a los agentes coloniales pero no del todo, generando así una ambivalencia que pueden instrumentalizar para sus propios fines. No otra cosa sucede, creo, con los togados de los santuarios iberorromanos.

A pesar de ser algo más tardía que los contextos que aquí estamos estudiando, creo ventajoso rescatar la singular noticia que Tácito nos ofrecía sobre la "romanización" impulsada por Agrícola en Britania, mencionada páginas atrás. A resultas de las presiones del gobernador romano, los britanos terminaron alcanzando en poco tiempo elevadas cotas de civilización, plasmadas entre otras cosas en el uso de la toga por parte de sus varones. Pero el mismo Tácito subraya que fueron los propios britanos quienes eligieron calarse la singular vestimenta romana: inde etiam habitus nostri honor et frequens toga ${ }^{30}$. Agrícola todo lo más, creó la coyuntura propicia para que aquellos individuos que optaran por la toga (léase, por la colaboración con las estructuras provincias romanas) se vieran más beneficiados que quienes la rechazaban en el juego político existente en el seno de las distintas comunidades locales. Pero participar en el juego valiéndose de unas u otras bazas era ya decisión de cada cual.

Otro tanto sucedió, con toda probabilidad, en tierras hispanas. Tras la inclusión de las diversas comunidades ibéricas bajo la égida romana, la competición por el poder entre las diversas familias aristocráticas no hizo sino arreciar en el seno de cada una de estas sociedades. La gran mayoría de los actores intervinientes se esforzó por velar los cambios producidos, refugiándose en la tradición para legitimar y naturalizar la nueva situación y el nuevo equilibrio de poderes propio del espacio provincial hispanorromano (García Cardiel 2016: 139-144). Pero algunos de estos actores, al parecer, consiguieron diferenciarse de sus competidores sintetizando esa (supuesta) tradición ibérica con los nuevos sistemas de referencia romanos. Al representarse revestidos de la toga, subrayaban ante sus respectivas comunidades sus conexiones privilegiadas con las estructuras provinciales romanas, y acaso lograban causar una mejor impresión ante los responsables de estas. Actuaban, por decirlo así, como

${ }^{30}$ Tac., Agric. 21.3. valedores de los intereses romanos en sus respectivas comunidades, a imagen de un Sífax, un Masinisa o un Prusias II. Pero ello no era óbice para que continuaran rindiendo culto en los santuarios de sus ancestros, a la manera en la que lo hicieron aquellos.

Puede que Lucio Licinio, el ciudadano romano (o latino) que se hizo representar togado en el Cerro de los Santos, no fuera el único aristócrata que, pese a gozar de un estatuto jurídico privilegiado, continuó acudiendo al santuario; pero sí fue uno de los pocos que optó por representarse como el heredero de lo antiguo y lo nuevo, entendiendo ambas cosas como una síntesis coherente. Por el contrario, otros siguieron aquella misma estrategia en el Cerro de los Santos a pesar de no contar, aparentemente, con la ciudadanía. La mayoría de los peregrinos, en cambio, continuó representándose al modo tradicional. Postura que no entrañaba por fuerza un rechazo a las estructuras provinciales romanas sino, sencillamente, una manera algo distinta de continuar cumpliendo con los ritos "tradicionales" locales.

Otro tanto sucedió, de hecho, por todo el mundo ibérico. Lo hemos observado en Torreparedones y en los Altos del Sotillo. El santuario de Muntanya Frontera, en cambio, parece que nos muestra el triunfo progresivo de una de estas estrategias ideológicas sobre las demás agendas alternativas. Aquí ya todos los peregrinos exhiben la toga. Ya no hay mujeres representadas entre ellos, como si el culto hubiera quedado vedado para ellas, o al menos la materialización del mismo en forma de exvotos antropomorfos. Y ya varios de los dioses venerados pueden identificarse claramente con divinidades grecorromanas. La sociedad, sin duda, cambiaba rápidamente.

\section{CONCLUSIONES}

En dos pasajes de su Geografía, Estrabón señala la afición de determinadas comunidades hispanas por vestir la toga (la stola, dice él, valiéndose de sus referentes culturales griegos para describir una construcción cultural romana). Menciona esta peculiaridad como indicador del elevado grado de "romanización" de estas sociedades concretas, en un salto interpretativo que ha sido asumido por buena parte de la historiografía moderna.

Sin embargo, hemos de reparar en que el geógrafo de Amasia escribía desde un contexto cultural algo distinto del que estaba describiendo. Tras las reformas de Augusto, el empleo de la toga había adquirido en Roma unas connotaciones que posiblemente no tenía en época tardorrepublicana, y que en todo caso difícilmente son extrapolables al ámbito provincial hispa- 
norromano de los siglos II y I a. C. Es cierto que la presencia de togados en las provincias nos habla del proceso de acusada hibridación cultural vigente en estos espacios, pero dicha hibridación no es un determinante, sino una precondición, para la difusión de la toga romana entre las comunidades locales. Al fin y al cabo, son numerosos los pueblos hispanos que, pese a encontrarse tanto o más asimilados a las estructuras culturales romanas según el propio Estrabón, no parecen sin embargo adeptos a tan singular atuendo.

La propia legislación romana es el otro condicionante necesario (pero no determinante) para el empleo de la toga. Como hemos visto, en época republicana no se hacía especial énfasis en el uso exclusivo de la toga por parte de los ciudadanos romanos, sino que el propio Senado fomentaba su uso entre los jerarcas extranjeros que de un modo u otro se mostraban partidarios de la causa romana. La toga era prenda de esa amicitia que, según recientes corrientes interpretativas, sirvió como pilar fundante del expansionismo imperial romano republicano (Burton 2011).

Más allá de estos condicionantes, pues, explicaremos mejor la temprana afición por la toga de ciertos hispanos estudiando las posibles motivaciones de los propios agentes locales. Y entendiendo que estas motivaciones, en un mundo multipolar conformado por sociedades fuertemente jerarquizadas y competitivas, habrán de ser forzosamente heterogéneas.

Atendiendo al registro arqueológico ibérico, observamos que en determinados santuarios extraurbanos ciertas elites locales se hicieron representar a sí mismas con la toga. Pero se trata siempre de representaciones perfectamente coherentes con las prácticas rituales y los comportamientos simbólicos que podemos considerar tradicionales en sus respectivas sociedades. Hablamos, pues, de ciertos jerarcas que se muestran respetuosos con los ritos de sus ancestros, reivindicando para sí, posiblemente, el prestigio inherente de la tradición; pero que matizan dicha tradición, haciéndola coherente con la nueva realidad hispanorromana de la que estos gobernantes (gobernantes por delegación de Roma, no lo olvidemos) son los principales beneficiados. Haciéndose representar togados en sus santuarios tradicionales, materializaban a través de su cuerpo y su apariencia la cosmología y el sistema de valores híbrido que legitimaban su preeminencia política, al tiempo que hacían alarde de sus conexiones con el poder romano. Es por ello que vestir la toga para participar en los rituales cívicos ibéricos tradicionales resultaba, desde su punto de vista, perfectamente apropiado.

No lo sería, en cambio para muchos de los otros actores intervinientes en la competición por el poder de las distintas comunidades. Ello explica que en los santuarios locales, eficaces escenarios de la confrontación política, se hicieran representar vistiendo unos atuendos tradicionales análogos a los de sus ancestros. Tan connotadas estaban sus vestimentas "ibéricas" como las togas. Unas y otras respondían, si lo pensamos bien, a distintas estrategias políticas.

A largo plazo, sabemos que las dinámicas históricas terminarían premiando algunas de estas estrategias y castigando otras. Si a la altura de los siglos II y I a. C. los individuos togados eran minoritarios en algunos santuarios, y estaban totalmente ausentes de otros, en tiempos de Estrabón había ya comunidades enteras que recibían el nombre de "estoladas/togadas". El propio santuario de Muntanya Frontera lo demuestra. Las limitaciones de nuestras fuentes, sin embargo, nos escamotean la intrahistoria de cada una de estas sociedades, y el devenir de las luchas de poder que se emprendieron en su seno.

\section{BIBLIOGRAFÍA}

Ahmad, A. 1995: "The politics of literary postcoloniality", Race and Class 36 (1), 1-20. https://doi. org/10.1177/030639689503600301

Alföldy, G. 2005: "Romanisation - Grundbegriff oder Fehlbegriff? Überlegungen zum gegenwärtigen Stand der Erforschung von Integrationsprozessen im römischen Weltreich", Z. Visy (ed.), Limes XIX. Proceedings of the XIX ${ }^{\text {th }}$ International Congress of Roman frontier Studies, Pécs, 25-56

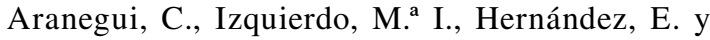
Graells, R. 2018: "La romanización de los bronces ibéricos: el conjunto de Muntanya Frontera de Sagunto (Valencia)", L. Prados, C. Rueda y A. Ruiz (eds.), Bronces ibéricos, una historia por contar. Libro homenaje al prof. Gérard Nicolini, Madrid, 455-490.

Badian, E. 1958: Foreign clientelae (264-70 a.C.), Oxford.

Baena, L. 1993: "Togati Hispaniae. Aproximación al estudio de las esculturas de togados en Hispania", Baetica 15, 165-174.

Baena, L. 1996. "Los togados de la Baetica: análisis epigráfico y escultórico”, J. Massó y P. Sada (eds.), II Reunión sobre escultura romana en Hispania, Tarragona, 31-48.

Balil, A. 1960: "Plástica provincial en la España romana”, Revista de Guimaraes 70 (1-2), 107-131.

Bardet, S. 2010: "Romanisation, utile outil historiographique ou notion idéologique à répudier", S. A . Beaune (dir.), Écrire le passé. La fabrique de la préhistoire et de l'histoire à travers les siècles, Paris, 209-219. 
Baronowski, D. W. 1984. "The Formula Togatorum", Historia 33, 248-252.

Barrett, J. C. 1997: "Romanization: a critical comment", D. J. Mattingly (ed.), Dialogues in Roman Imperialism. Power, discourse, and discrepant experience in the Roman Empire, Journal of Roman Archaeology Suppl. Series 23, Portsmouth, 51-64.

Beltrán, F. 2017: “Acerca del concepto de romanización”, T. Tortosa y S. Ramallo (eds.), El tiempo final de los santuarios ibéricos en los procesos de impacto y consolidación del mundo romano, Anejos de Archivo Español de Arqueología LXXIX, Madrid, 17-26.

Bhabha, H. J. 1994: The location of culture, London.

Blázquez, J. M. 2006: "La Hispania en época de Augusto vista por los escritores contemporáneos. Estrabón y Trogo Pompeyo", Gerión 24 (1), 237-249.

Blech, M. 1999: "Exvotos figurativos de santuarios de tradición ibérica en la época romana en la Alta Andalucía”, V. Salvatierra y C. Rísquez (eds.), De las sociedades agrícolas a la Hispania romana, Jaén, 143-174.

Boric, D. y Robb, J. 2008: Past bodies: body-centered research in Archaeology, Oxford.

Brotons, F. y S. F. Ramallo 2017: “Continuidades y cambios en los santuarios ibéricos del Sureste de Iberia: los templos in antis del Cerro de los Santos y del Cerro de la Ermita de la Encarnación", T. Tortosa y S. F. Ramallo (eds.), El tiempo final de los santuarios ibéricos en los procesos de impacto y consolidación del mundo romano, Anejos de Archivo Español de Arqueología LXXIX, Madrid, 93-116.

Bulger, D. y R. A. Joyce 2012: "Archaeology of embodied subjectivities", D. Bulger (ed.), A companion to gender prehistory, Oxford, 68-85.

Burton, P. J. 2011: Friendship and empire: Roman diplomacy and imperialism in the middle Republic (353-146 BC), Cambridge.

Canto, A. M. 2001: "Sinoicismo y stolati en Emerita, Caesaraugusta y Pax: una relectura de Estrabón III, 2, 15", Gerión 19, 425-476.

Carroll, M. 2015: "Projecting self-perception on the Roman frontiers: the evidence of dress and funerary portraits", D. J. Breeze, R. H. Jones e I. A. Oltean (eds.), Understanding Roman frontiers. A celebration for Professor Bill Hanson, Edimburgh, 154-166.

Chapa, T. 1984: "El Cerro de los Santos (Albacete). Excavaciones desde 1977 a 1981”, Al-Basit 15, 109-124.

Chapot, M. 1937: "Propos sur la toge", Mémoires de la Societé Nationale des Antiquaires de France 80, 37-66.
Civera, M. 2014-2015: "El santuari de la Muntanya Frontera de Sagunt (de Tu a Liber Pater)", Arse 48-49, 151-172.

Cleland, L., Harlow, M. y Llewellyn-Jones, Ll. (eds.) 2005: The clothed body in the Ancient World, Oxford.

Cruz, G. 2002-2003: "La construcción de los espacios políticos ibéricos entre los siglos III y I a.C.: algunas cuestiones metodológicas e históricas a partir de Polibio y Estrabón", Cuadernos de Prehistoria y Arqueología 28-29, 35-54. https://doi. org/10.15366/cupauam2003.29.003

Cruz, G. 2007: "Acerca de Estrabón y la TurdetaniaBética”, G. Cruz, P. Le Roux y P. Moret (eds.), La invención de una geografía de la Península Ibérica II. La época imperial, Málaga, 251-270.

Curchin, L. A. 1990: The local magistrates of Roman Spain, Toronto.

Davies, G. 2005: "What made the Roman toga virilis?", L. Cleland, M. Harlow y Ll. Llewellyn-Jones (eds.), The clothed body in the Ancient World, Oxford, 121-130.

De Hoz, J. 2011: Historia Lingüística de la Península Ibérica en la Antigüedad. II: El mundo ibérico prerromano y la indoeuropeización, Madrid.

Díaz, B. 2008. Epigrafía latina republicana de Hispania, Barcelona.

Dmitriev, S. 2009: “( Re-)constructing the Roman empire: from «imperialism» to «post-colonialism». An historical approach to history and historiography", Annali della Scuola Normale Superiore di Pisa 5, 123-164.

Edmonson, J. 2008: "Public dress and social control in late republican and early imperial Rome", J. Edmonson y A. Keith (eds.), Roman dress and the fabric of Roman culture, Toronto, 21-46.

Fernández Castro, M. C. y Cunliffe, B. W. 2002: El yacimiento y el santuario de Torreparedones. Un lugar arqueológico preferente en la campiña de Córdoba, Oxford.

García y Bellido, A. 1943: "Algunos problemas de arte y cronología ibéricos", Archivo Español de Arqueología 16, 78-108.

García Cardiel, J. 2015: "El Cerro de los Santos: paisaje, negociación social y ritualidad entre el mundo ibérico y el hispano", Archivo Español de Arqueología 88, 85-104. https://doi.org/10.3989/ aespa.088.015.005

García Cardiel, J. 2016: Los discursos del poder en el mundo ibérico del Sureste (siglos VII-I a.C.). Bibliotheca Praehistorica Hispana 32, Madrid.

García Fernández, E. 2009: "Reflexiones sobre la latinización de Hispania en época republicana", J. Andreu, J. Cabrero e I. Rodà (eds.), Hispaniae. Las 
provincias hispanas en el mundo romano, Girona, 377-390.

George, M. 2008: “The 'Dark Side' of the Toga", J. Edmonson y A. Keith (eds.), Roman dress and the fabric of Roman culture. Toronto, 94-112.

Goethert, F. W. 1939: "Studien zur Kopienforschung. Die stil- und trachgeschischtliche Entwicklung der Togastatue in den beiden ersten Jahrhunderten der römischen Kaiserzeit", Römische Mitteilungen 54, 176-219.

Goette, H. R. 1990: Studien zu römischen Togadarstellungen, Mainz.

Gregory, A. P. 1994: “"Powerful images': responses to portraits and the political uses of images in Rome", Journal of Roman Archaeology 7, 80-99. https:// doi.org/10.1017/s1047759400012514

Hamilakis, Y., Pluciennik, M. y Tarlow, S. (eds.) 2002: Thinking through the body. Archaeologies of corporeality, New York.

Hanson, W. S. 1997: "Forces of change and methods of control", D. J. Mattingly (ed.), Dialogues in Roman Imperialism. Power, discourse, and discrepant experience in the Roman Empire, Journal of Roman Archaeology Suppl. Series 23, Portsmouth, 67-80.

Hæussler, R. 2013: Becoming Roman? Diverging identities and experiences in Ancient Nortwest Italy, London.

Heuzey, L. 1922: Histoire du costume antique d'après le modèle vivant, Paris.

Izquierdo, I. y Velaza, J. 2002: "Estudio de una escultura con inscripción ibérica procedente del Cerro de los Santos", Sylloge Epigraphica Barcinonensis 4, 31-42.

Jiménez, A. 2011: "Pure hybridism: Late Iron Age sculpture in southern Iberia", World Archaeology 43 (1), 102-123. https://doi.org/10.1080/00438243. 2011.544903

Kleiner, D. E. E. 1977: Roman group portraiture. The funerary reliefs of the Late Republic and Early Empire, New York.

Larsson Lovén, L. 2014: "Clothes, body language, and visual communication in ancient Rome", $\mathrm{H}$. Alexandersson y A. Andreeff (eds.), Med hjärna: En vänbok till professor Elisabeth Arwill-Nordbladh, Göteborg, 429-441.

Laserre, F. 1966: Strabon. Géographie (livres III et IV), Paris.

León, M. P. 1981: "Plástica ibérica e iberorromana", La baja época de la cultura ibérica, Madrid, 181-199.

Le Roux, P. 1995: Romains d'Espagne. Cités \& politiques dans les provinces, IIe siècle av. J.-C. - III siècle ap. J.-C., Paris.
Lo Cascio, E. 1991-1994. "I togati della formula togatorum”, Annali dell'Istituto Italiano per gli Studi Storici 12, 309-328.

Malkin, I. 2011: A small Greek world. Networks in the Ancient Mediterranean, Oxford.

Mattingly, D. J. 2011: Imperialism, power, and identity. Experiencing the Roman Empire, Princeton.

Melchor, E. 2009: "Las elites municipales hispanorromanas a fines de la República y en el Alto Imperio: ideología y conductas sociopolíticas", J. Andreu, J. Cabrero e I. Rodà (eds.), Hispania: las provincias hispanas en el mundo romano, Girona, 391-410.

Millett, M. 2010: The Romanization of Britain: an essay in archaeological interpretation, Cambridge.

Morena, J. A. 1989: El santuario ibérico de Torreparedones (Castro del Río-Baena, Córdoba), Córdoba.

Morena, J. A. 2017: Arquitectura, iconografía y culto en el santuario iberorromano de Torreparedones (Baena, Córdoba), Córdoba.

Niemeyer, H. G. 1968: Studien zur Statuarischen darstellung der Römischen Kaier, Berlin.

Noguera, J. M. 1994: La escultura romana de la provincia de Albacete (Hispania Citerior - Conventus Carthaginensis), Albacete.

Noguera, J. M. y Rodríguez Oliva, P. 2008: "Scultura ispànica in epoca repubblicana: note su generi, iconografia, usi e cronologia”, J. Uroz, J. M. Noguera y F. Coarelli (eds.), Iberia e Italia: modelos romanos de integración territorial, Murcia, 379-454.

Olcina, M. H. 2009: Lucentum. Historia y arqueología, Alicante.

Olmos, R. 2007-2008: "Ex Ilici dictum. La fundación mítica de la Colonia Iulia Ilice Augusta", Rendiconti della Pontificia Accademia Romana di Archeologia 80, 193-215.

Prabhu, A. 2007: Hybridity: limits, transformations, prospects, New York.

Ramallo, S. F. y Brotons, F. 2014: "Depósitos votivos y ritos en los santuarios ibéricos de íbero-romanos. Continuidades y rupturas a través de las evidencias de culto en el santuario del Cerro de la Ermita de la Encarnación (Caravaca de la Cruz, Murcia)", T. Tortosa (ed.), Diálogo de identidades. Bajo el prisma de las manifestaciones religiosas en el ámbito mediterráneo (s. III a.C. - s. I d.C.), Anejos de Archivo Español de Arqueología LXXII, Madrid, 17-44.

Ramallo, S. F., Brotons, F. y Noguera, J. M. 1998: “El Cerro de los Santos y la monumentalización de los santuarios ibéricos tardíos", Revista de Estudios Ibéricos 3, 11-69.

Rodà, I. 1998: "La difícil frontera entre escultura ibérica y escultura romana”, C. Aranegui (coord.), Los 
iberos, príncipes de Occidente. Estructuras de poder en la sociedad ibérica, Barcelona, 265-273.

Rodríguez Gutiérrez, O. 2012: "Sobre las imágenes de privados como esculturas. Algunas reflexiones en torno a los mecanismos de autorrepresentación ciudadana", Spal 21, 107-126. https://doi.org/10.12795/ spal.2012.i21.07

Rodríguez Ramos, J. 2002: "La inscripción sobre escultura de Cerro de los Santos G.14.1 y los problemas de homomorfia en la escritura íbera meridional", Habis 33, 203-211.

Ronda, A. M. y Tendero, M. 2014: "Producciones locales de época augustea de Ilici: las imitaciones de paredes finas y de la vajilla metálica romana", $\mathrm{R}$. Morais, A. Fernández y M. J. Sousa (eds.), As produções cerámicas de imitação na Hispania 1, Porto, 191-213.

Rothe U. 2009: Dress and cultural identity in the Rhine-Mosele Region of the Roman Empire. BAR International Series 2038, Oxford.

Rothfus, M. A. 2010: “The 'Gens Togata': changing styles and changing identities", The American Journal of Philology 131 (3): 425-452. https://doi. org/10.1353/ajp.2010.0009

Ruano, E. 1988: "El Cerro de los Santos (Montealegre del Castillo, Albacete): una nueva interpretación del santuario", Cuadernos de Prehistoria y Arqueología 15, 253-273. https://doi.org/10.15366/ cupauam1988.15.008

Rueda, C. 2011: "Modelos de interacción: la divinidad como instrumento de análisis en los procesos de transformación de la sociedad ibera (siglos III a.C. - I d.C.)", Epigrafia e antichità: identità e autonomie nel mondo romano occidentale. Iberia-Italia, Italia-Iberia. III Convegno Internazionale di Epigrafia e Storia Antica, Milano, 107-140.
Ruiz Bremón, M. 1986: "Esculturas romanas en el Cerro de los Santos", Archivo Español de Arqueología 59, 67-88.

Ruiz Bremón, M. 1987-1988: "Esculturas del Cerro de los Santos en Valencia”, Saguntum 21, 331-360.

Ruiz Bremón, M. 1989: Los exvotos del santuario ibérico del Cerro de los Santos, Albacete.

Simón, I. 2012: "La epigrafía ibérica de Montaña Frontera", Madrider Mitteilungen 53, 239-261.

Van Oyen, A. 2015: "Deconstructing and reassembling the Romanization debate through the lens of postcolonial theory: from global to local and back?", Terra Incognita 6: 205-226.

Velaza, J. 2007: “Aspectos en torno a la escritura y la lengua ibérica en el Sureste de la Meseta meridional", G. Carrasco (coord.), Los pueblos prerromanos en Castilla-La Mancha, Cuenca, 271-284.

Vout, C. 1996: "The myth of the toga: understanding the history of Roman dress", Greece \& Rome 43 (2), 204-220. https://doi.org/10.1093/gr/43.2.204

Wallace-Hadrill, A. 2012: "The creation and expression of identity. The Roman World", S. Alcock y R. Osborne (eds.), Classical Archaeology. Second Edition. Blackwell Studies in Global Archaeology, Chichester, 368-393.

Whittaker, D. 2009: "Ethnic discourses on the frontiers of Roman Africa", T. Derks y N. Roymans (eds.), Ethnic constructs in Antiquity. The role of power and traditions, Amsterdam, 189-205.

Wilson, L. M. 1924: The Roman toga, Baltimore.

Woolf, G. 1998: Becoming Roman: the origins of provincial civilization in Gaul, Cambridge.

Recibido: 29-11-2018

Aceptado: 14-03-2019 